\title{
SECONDARY SCHOOL TEACHERS' PERCEPTIONS OF THE CHALLENGES AND SOLUTIONS TO ONLINE ASSESSMENT OF LEARNING
}

\author{
Ezeugo Nneka Chinyere ${ }^{i}$ \\ Department of Educational Foundations, \\ Nnamdi Azikiwe University, \\ Awka, Anambra State, \\ Nigeria \\ orcid.org/0000-0002-3680-3150
}

\begin{abstract}
:
The study determined secondary school teachers' perceptions of the challenges and solutions to online assessment of learning. The study is a descriptive survey guided by two research questions and two null hypotheses tested at 0.05 level of significance. The instruments for data collection were Digital Literacy Test (DLT) and a structured questionnaire titled: Challenges and Solutions to Online Assessment of Learning (CASOAL). The reliability of DLT was determined using Kuder-Richardson formula 20 to be 0.81 and that of CASOAL was determined using Cronbach Alpha to be 0.72 . The instrument was administered via telegram-x platform of secondary school teachers in Anambra state using Google forms. Data generated from the study were analysed using descriptive statistics and Anova. The findings revealed that secondary school teachers' perceptions about the challenges and solutions to online assessment include among other things: poor internet connectivity in rural and remote areas, indication of poorer level of performance for students who struggle with technology; lack of certainty in terms of academic integrity and cheating; difficulty in scoring and correcting questions with open responses. It was recommended among others that school administrators should organise orientation for students and professional training for teachers on the use of online assessment.
\end{abstract}

Keywords: teachers' perception, digital literacy, online assessment, learning, challenges solutions

\section{Introduction}

Technological advancements have continued to offer a wide range of potential benefits to the teaching and learning process and these benefits have also extended to the online

i Correspondence: email nc.ezeugo@unizik.edu.ng, nnekaezeugo@yahoo.com 
assessment of learning. An online assessment is an evaluation of a person's abilities, behaviours and/or characteristics conducted over the internet by using available web technologies (Abdulghani, 2020). It refers to a process of conducting a test online to measure the knowledge of the participants on a given topic (Easy LMS B. V., 2021). Online assessment is an emerging field that adopts technology in a networked environment to improve the quality and efficiency of assessing learner's knowledge, skills, and abilities (Mayotte, 2012; p1). The advantages of online assessment are often described in terms of its administrative convenience, efficiency and lower costs. Effective online assessments are also capable of providing more timely, more instructionally useful feedback to teaching and learning (Masters; Thomson \& Schleicher, 2017; p.1). Instant feedback which is just one among the many benefits of online assessment gives the students an immediate sense of how well they have performed (Noradila, Nishantini \& Nur, 2021). It provides information on relevant areas they need to work on thereby increasing the level of engagement with the subject. Again, assessments of learning via online platforms according to Alruwais, Willsa and Wald (2018) are particularly suited for closed questions and large number of students, providing easy scoring technique with little effort for the teacher. The assessment can be administered over the web with students taking part from virtually any location with a computer connected to the internet. It is for this reason that online assessment has gained wider acceptance in recent times.

Electronic learning experts and educational technologists have continued to emphasize that online assessment can play an important role in improving the quality of students' learning(Barbosa \& Garcia-Penalvo, 2005; Mayotte, 2012). This claim has gained unanimous acceptance from educational instructors given the need for social distancing consequent upon the recent Covid-19 Pandemic (Vlachopoulos, 2020). The pandemic era resulted in indispensable educational policy changes across the world (Strunc, 2020). Nations of the world including Nigeria are made efforts to ensure a smooth paradigm shift from traditional face to face learning to more online learning. This shift equally demands online assessment of the learning process. This is evident as most States of the Federation adopted learning instructions via online Zoom and Skype social application software (World Bank, 2020). Media stations were deployed to handle instructions for examination classes at specific times nation-wide and state-wise. However, some schools did not adopt online assessment but resorted to the traditional paper pencil assessment technique despite the danger of the pandemic.

The need to conduct assessment during pandemic was a daunting task for almost all educational agencies and stakeholders. Although, the benefits of online assessment was clear at such a time, educational stakeholder and teachers never gave online assessment a serious thought especially at the secondary school level of education. Those that tried ran into myriads of problems. Stakeholders and educational agencies instead mapped out Covid-19 guidelines for schools to strictly adhere to in the conduct of termly assessments. The indecision to seriously adopt online assessment at the secondary school level, even during the lockdown is an indication that educational stakeholders and 
secondary school teachers at large may have varied perceptions about online assessment especially as it relates to the challenges of its adoption.

Studies by Ramazan (2017) showed that one of the most frequently perceived problems the lecturers encountered in implementing online assessment include not being able to prevent cheating during the exams. In carrying out assignments and projects students often used the same assignments by copying from each other and/or they copy/paste things they found on internet. Moreover, the process of preparing and evaluating online exams and assignments require a lot of time and effort.In a study by Mirza( 2021) on university teachers' perception of online assessment during Covid-19 in Lebanon, it was observed that "all participants agreed that the university's web-based system was not well developed to handle the tests of a large number of students, monitor test-taking and prevent cheating" (p.21). They were equally of the opinion that adequate guidance was not provided; therefore, they preferred to avoid using online exams and quizzes. The findings of Mariam (2021) revealed that the teachers' perception of online assessment includes but are not limited to: lack of physical interaction, poor assessment of speaking and translation courses, high risk of cheating and plagiarism, technical difficulties, and problem of guarantying the integrity of online assessment. The findings of Fedelis and Harwati (2021) equally revealed that teachers perceive online assessment as difficult due to slow network transmission, lack of facilities, accessibility to reliable gadgets and time needed by teachers to apply online assessment tools. The challenge of network is further collaborated by Emmanuel (2020), who stated the teachers found it difficult to upload large notes.

Online assessment of learning affords both the teacher and students a lot of benefits but presents many challenges especially for developing countries like Nigeria. On a first instance, most public secondary schools do not have the requisite infrastructure to conduct online assessment. The cost of installation of the needed online assessment technology is high and cannot be afforded in least possible time. Also, with the epileptic power supply in the country, the possibility of conducting online assessment effectively is obviously slim. There is also the problem of poor technological skills among secondary school students who may not be ready for an online assessment of learning programmes. Kearns (2012) outlined four basic challenges to online assessment. They include challenges as a result of the impact of physical distance between the instructor and the students, difficulties in applying technological tools in communicating with the students, teachers work load and time constraints, demands of varied assessment data and feedback needs although, these are general views to the possible challenges of online assessment of learning, secondary school teachers may have some peculiar views as the true curriculum implementers. It was pertinent therefore, that a study be conducted to empirically establish the perceptions of secondary school teachers on the use of online assessment.

The ability to use online assessment and the perceptions of its usage may, however, be subject to secondary school teachers' level of digital literacy. Digital literacy is the set of competencies required for full participation in a knowledge society 
(Gomathy, 2018). It includes according to Gomathy, knowledge, abilities, and behaviours involving the effective use of digital devices such as $\underline{\text { smart }}$ phones, tablets, laptops and desktop, personal computers for purposes of communication, expression, collaboration and advocacy. According to Western Sydney University(2020),digital literacy entails having the skills needed to effectively live and function in a society predominantly dependent on digital technologies for effective communication and information retrieval. Such technologies include internet platforms, social media, and mobile devices. Gomathy further noted that the focus of digital literacy has shifted from stand-alone to network devices including the internet and social media. Eyiuche and Adebowale (2020) established that there was a low extent of digital disparity in ICT knowledge of secondary school teachers in Anambra state. However, there is need to explore the differences in perception of secondary school teachers on the challenges of online assessment based on their digital literacy.

To effectively deal with the challenges of online assessments, teachers at the secondary school level who are the ones to administer the assessment stand a better position to suggest possible solutions that can alleviate the challenges of online assessment. Again, the perception of the possible solutions of the secondary school teachers may be determined by their level of digital literacy. In his own study, Ramazan (2017) reported that teachers perceived the following possible solutions to online assessment: giving students assignments and practices that will not require memorizing but will enable them to use high-order thinking skills and prevent them from cheating; providing students and lecturers with trainings on online assessment and evaluation practices; increasing the encouragement and motivation of lecturers on developing online assessment and evaluation practices etc. Guangul, Suhail, Khalit, and Khidhir (2020) equally found that preparing different questions for each student, use of online presentations, and combining various assessment methods could be some of the ways of meeting up with the challenges of online assessment. The present study focused on the determination of the secondary school teachers' perceptions of the challenges and solutions to online assessment bearing in mind the level of their digital literacy.

\section{Purpose of the Study}

The study determined the secondary school teachers' perceptions of the challenges and solutions to online assessment of learning. Specifically, the study determined the:

- Perceptions of secondary school teachers on the challenges of online assessment of learning in Anambra state.

- Perceptions of secondary school teachers on the solutions to the challenges of online assessment of learning in Anambra state.

- Differences between the mean perceptions of secondary school teachers in Anambra state on the challenges of online assessment of learning based on the level of digital literacy; 
- Differences between the mean perceptions of secondary school teachers in Anambra state on the solutions to the challenges of online assessment of learning based on the level of digital literacy.

\subsection{Research questions}

The following research questions were raised to guide the study.

- What are the perceptions of secondary school teachers on the challenges of online assessment of learning in Anambra state?

- What are the perceptions of secondary school teachers on the solutions to the challenges of online assessment of learning in Anambra state?

\subsection{Hypotheses}

- There is no significant difference between the mean perceptions of secondary school teachers in Anambra state on the challenges of online assessment of learning based on their level of digital literacy.

- There is no significant difference between the mean perceptions of secondary school teachers in Anambra state on the solutions to the challenges of online assessment of learning based on the level of digital literacy.

\section{Methodology}

The design adopted for the study was descriptive survey. According to Nworgu (2015), survey research is one in which a group of people or items is studied by collecting and analyzing data from only a few people or items considered to be representative of the entire group. The area of this study was Anambra state. The state has six education zones namely, Aguata, Awka, Nnewi, Onitsha, Ogidi and Otuocha with 259 public secondary schools. The population of the study consisted of 3,395 senior secondary schools teachers. The sample size for the study was 848 teachers representing $25 \%$ of the population. The sample was obtained using accidental sampling.

The instruments used for data collection were Digital Literacy Test (DLT) and a structured questionnaire titled: Challenges and Solutions to Online Assessment of Learning (CASOAL). DLT was a 20-item multiple choice questions lettered options A-D. The questions were taken from standardized past examination questions from computer studies and data processing. It covered questions on computer appreciation and Microsoft word. The test was designed to determine the level of digital literacy of the teachers. Each question was designed to last 20 seconds and the entire test was programmed to auto-submit as the test time elapsed. The score of the teachers was used to categorize them into three digital literacy levels of high, moderate and low.

CASOAL had three sections. Section A was designed to generate demographic information from the teachers. Section B contained 15 items constructed to generate information on the challenges of online assessment of learning while section $C$ was designed to generate information on the solutions to the challenges of online assessment 
of learning using 10 items. The response pattern adopted for sections B and $C$ was a four point rating scale of Strongly agree (SA), Agree (A), Disagree and (D), Strongly disagree (SD).

The initial draft of the instrument, objectives, research questions and hypotheses were given to two experts from Department of Educational Foundations, Nnamdi Azikiwe University, Awka. They were expected to validate the content, construct, language and the relatedness of the instrument to the study to the study. They were also requested to vet the clarity of the sentences and to write R (retain), M (modify), D (delete) against any questions and items they wish the researcher to retain, modify or delete respectively. Their suggestion and corrections were effected in the final copy of the instrument. The reliability of DLT was determined Kuder-Richardson Formula 20 (KR20) while that of CASOAL was established using Cronbach Alpha. Both Instruments were administered once to 10 public secondary school teachers who were not involved in the study. The coefficient of internal consistency obtained for the DLT was 0.81, while that of CASOAL was 0.72 .

Both instruments were posted on the telegram-x platforms of the secondary school teachers in the state. The instruments were administered to the teachers with the help of google forms. The link is online survey development cloud-based software which functions as a service application, providing free, customizable surveys, as well as a suite of free back-end programs that include data analysis, sample selection, bias elimination and data representation tools. The test was programmed to self-submit at the end of the elapsed question time while teachers who did not fill the questionnaire were not be able to submit it except, they go back and fill the particular items they missed out. After submitting a completely filled questionnaire, the application collated and sent the response pattern and summated scores of each teacher's answers to the questions and response to the researcher's default e-mail address automatically. Only $84.6 \%$ of the instrument sent out was retrieved.

Data obtained from the study was analysed using descriptive statistics and oneway Analysis of Variance (ANOVA). The research questions were answered using weighted response average where the item by item mean and standard deviation were computed. The decision for the acceptability of each item was based on a cut-off (boundary) mean of 2.5. Thus, any item with mean above or equals 2.5 was accepted whereas items with mean below 2.5 were rejected. The decision rule for the hypotheses was that where the P-value was less than 0.05 , the null hypotheses was rejected, otherwise the null hypotheses was accepted.

\section{Results}

Research Question 1: What are the perceptions of secondary school teachers on the challenges of online assessment of learning? 
Table 1: Challenges perceived in online assessment of learning

\begin{tabular}{|c|c|c|c|c|}
\hline $\mathrm{S} / \mathrm{N}$ & Items & $\bar{x}$ & SD & Decision \\
\hline 1 & $\begin{array}{l}\text { Poor internet connectivity is a big problem in rural and remote areas } \\
\text { as it interferes with the smooth flow and execution of assessment }\end{array}$ & 3.02 & 1.02 & Agree \\
\hline 2 & $\begin{array}{l}\text { The quality of the question banks and its accuracy may not } \\
\text { represent true assessment }\end{array}$ & 2.32 & 0.34 & Disagree \\
\hline 3 & $\begin{array}{l}\text { Online assessments are only well suited to closed questions with a } \\
\text { limited range of possible answers }\end{array}$ & 2.83 & 0.92 & Agree \\
\hline 4 & $\begin{array}{l}\text { For students who struggle with technological skills, online } \\
\text { assessments may lead to a poorer level of performance in the subject } \\
\text { than the student may demonstrate in other assessment contexts }\end{array}$ & 2.64 & 1.83 & Agree \\
\hline 5 & $\begin{array}{l}\text { There is lack of certainty in terms of academic integrity and } \\
\text { cheating, since anyone could accompany the student while they } \\
\text { undertake online assessment especially when served over the web }\end{array}$ & 3.22 & 0.64 & Agree \\
\hline 6 & $\begin{array}{l}\text { There is great difficulty in scoring and correcting questions with } \\
\text { open responses that require explanation }\end{array}$ & 3.21 & 0.33 & Agree \\
\hline 7 & $\begin{array}{l}\text { Most secondary schools do not have the requisite infrastructure } \\
\text { needed for effective conduct of online assessment }\end{array}$ & 3.80 & 0.75 & Agree \\
\hline 8 & $\begin{array}{l}\text { Many secondary school teachers do not have the competency skills } \\
\text { needed for online assessment }\end{array}$ & 2.57 & 1.84 & Agree \\
\hline 9 & $\begin{array}{l}\text { Preparation and evaluation of online assessment requires a lot of } \\
\text { time and effort }\end{array}$ & 2.72 & 1.27 & Agree \\
\hline 10 & $\begin{array}{l}\text { The cost implication of online assessment is much compared to } \\
\text { traditional assessment }\end{array}$ & 3.84 & 1.01 & Agree \\
\hline 11 & There is possibility of impersonation in online assessment & 2.55 & 1.48 & Agree \\
\hline 12 & $\begin{array}{l}\text { Given the population of the students taking the assessment, time } \\
\text { management may become a huge problem }\end{array}$ & 2.81 & 0.52 & Agree \\
\hline 13 & $\begin{array}{l}\text { It creates anxiety in the students especially those with poor digital } \\
\text { literacy }\end{array}$ & 2.77 & 1.28 & Agree \\
\hline 14 & $\begin{array}{l}\text { Online assessment occurs without the teachers' presence increasing } \\
\text { risk of assessment accountability }\end{array}$ & 2.12 & 0.71 & Disagree \\
\hline 15 & $\begin{array}{l}\text { Students often need training or brief orientation to be able to take } \\
\text { online assessment }\end{array}$ & 2.39 & 0.81 & Disagree \\
\hline
\end{tabular}

Cut-off mean $=2.5$

Table 1 shows that all the items except items 2, 14 and 15 have means above the cut-off mean of 2.5 which implies that secondary school teachers perceive them to be the challenges to online assessment of learning. Thus, some of the challenges to online assessment of line among others include the challenge of: internet connectivity in rural and remote areas which interferes with the smooth flow and execution of assessment; lack of suitability for closed questions with a limited range of possible answers; indication of poorer level of performance for students who struggle with technology; lack of certainty in terms of academic integrity and cheating; difficulty in scoring and correcting questions with open responses that require explanation; lack of the requisite infrastructure needed for effective conduct of online assessment; lack of competency skills needed for online assessment among secondary school teachers; lots of time 
required for preparation and evaluation of online assessment, high cost implication; time management; and the need for orientation and training of students for online assessment.

Research Question 2: What are the perceptions of secondary school teachers on the solutions to the challenges of online assessment of learning?

Table 2: Perceived solutions to the challenges of online assessment of learning

\begin{tabular}{|c|l|c|c|c|}
\hline S/N & \multicolumn{1}{|c|}{ Items } & $\bar{x}$ & SD & Decision \\
\hline 1 & $\begin{array}{l}\text { Latest technologies that ensures good connectivity should be acquired } \\
\text { and installed in secondary schools }\end{array}$ & 3.52 & 0.38 & Agree \\
\hline 2 & $\begin{array}{l}\text { Mock assessments should be organised for students before the main } \\
\text { assessment to familiarise with the online assessment techniques }\end{array}$ & 3.22 & 0.62 & Disagree \\
\hline 3 & Build in ways for learners to give feedback on any form of assessment & 2.84 & 1.05 & Agree \\
\hline 4 & $\begin{array}{l}\text { Giving learners the option to determine how they can best communicate } \\
\text { to you what they have learned }\end{array}$ & 2.19 & 1.73 & Disagree \\
\hline 5 & $\begin{array}{l}\text { Peer and team assessments can help motivate best efforts as well as help } \\
\text { students learn from each other }\end{array}$ & 2.47 & 0.97 & Disagree \\
\hline 6 & $\begin{array}{l}\text { Online assessment such as online discussion and personal activities in } \\
\text { solving learning problems should sometimes be adopted instead of } \\
\text { continuous close-ended questions }\end{array}$ & 2.93 & 0.77 & Agree \\
\hline 7 & $\begin{array}{l}\text { Development of mal-practice check software that prevent access to } \\
\text { other platforms during online assessment }\end{array}$ & 2.82 & 1.19 & Agree \\
\hline 8 & $\begin{array}{l}\text { Use of biometric login to prevent impersonation during online } \\
\text { assessment }\end{array}$ & 3.72 & 0.63 & Agree \\
\hline 9 & $\begin{array}{l}\text { Creation of teachers' or invigilators' virtual presence through a webbed } \\
\text { network to monitor online assessment }\end{array}$ & 3.11 & 0.84 & Agree \\
\hline 10 & $\begin{array}{l}\text { Frequently professional online assessment workshop and development } \\
\text { trainings for secondary school teachers. }\end{array}$ & 3.16 & 0.79 & Agree \\
\hline
\end{tabular}

Cut-off mean $=2.5$

Table 2 shows that all the items except items 4 and 5 have means that are above the cutoff mean. Thus, secondary school teachers agree to the following solutions to the challenges of online assessment: use latest technologies that ensures good connectivity, organisation of mock assessment to familiarize students with online assessment techniques before main assessment, building feedback mechanism on any form of assessment from students, use of online discussion and personal activity forms of online assessment, development of mal-practice check software plug-in to check access to other online platforms, use of biometric login to prevent impersonation, creation of virtual presence and professional development training on online assessment.

Hypothesis 1: There is no significant difference between the mean perceptions of secondary school teachers on the challenges of online assessment of learning based on the levels of digital literacy. 
Table 3: Perceptions on challenges of online assessment based on digital literacy levels

\begin{tabular}{|l|c|c|c|c|c|}
\hline Source of Variation & Sum of Squares & Df & Mean Square & F & Sig. \\
\hline Between Groups & 115.581 & 2 & 57.791 & \multirow{2}{*}{1.841} & \multirow{2}{*}{.159} \\
\hline Within Groups & 22450.391 & 715 & 31.399 & & \\
\hline Total & 22565.972 & 717 & & & \\
\hline
\end{tabular}

Table 3 shows the difference between the mean perceptions of secondary school teachers on challenges of online assessment based in digital literacy level using ANOVA. At 0.05 level of significance, the F-calculated was 1.841 with a P-value of 0.159 which is greater than 0.05 . The null hypothesis was accepted. Therefore, there is no significant difference between the mean perceptions of secondary school teachers on the challenges of online assessment of learning based on the levels of digital literacy.

Hypothesis 2: There is no significant difference between the mean perceptions of secondary school teachers on the solutions to the challenges of online assessment of learning based on the levels of digital literacy.

Table 4: Perceptions on solutions to challenges of online assessment based on digital literacy levels

\begin{tabular}{|c|c|c|c|c|c|}
\hline Source of Variation & Sum of Squares & df & Mean Square & $\mathbf{F}$ & Sig. \\
\hline Between Groups & 2.020 & 2 & 1.010 & \multirow{2}{*}{.113} & \multirow{2}{*}{.893} \\
\hline Within Groups & 6381.068 & 715 & 8.925 & & \\
\hline Total & 6383.088 & 717 & & & \\
\hline
\end{tabular}

Table 4 shows the difference between the mean perceptions of secondary school teachers on solutions to challenges of online assessment based on digital literacy levels using ANOVA. At 0.05 level of significance, the F-calculated was 0.113 with a P-value of 0.893 which is greater than 0.05 . The null hypothesis was accepted. Therefore, there is no significant difference between the mean perceptions of secondary school teachers on the solutions to the challenges of online assessment of learning based on the levels of digital literacy.

\section{Discussion}

The findings of the study showed that one of the perceptions of secondary school teachers on the challenges of online assessment of learning is poor internet connectivity. With particular reference to rural and remote areas, poor internet connectivity interferes with the smooth flow and execution of assessment. Some schools in Anambra state are not within the networks' bandwidth of some of the internet service providers. Transmission and reception of signal and data packets therefore become poor. This finding is in line with the findings of Emmanuel (2020), who reported that teachers have challenges when uploading large number of notes at the same time during online teaching due to poor network. Such poor networks could result into loss of internet service and connectivity 
and eventual wiping out of answers students have already provided. This is in line with the findings of Mariam (2021) and Fedelis and Harwati (2021) that poor internet connectivity is perceived as a challenge to usage of online assessment of learning by teachers. Again, the finding showed that teachers perceive online assessment to be only suitable for closed questions with a limited range of possible answers. This is because most cloud based software that provides end-to-end feedback and which are often used in online assessment requires selection of close-ended options. Cheating is also common, as there are no visible invigilators like in tradition assessment. Students may consult their books or by-pass through other internet gateways to assess the internet as they answer questions. This finding supports the findings of Ramazan (2017) that online assessment makes it difficult to prevent cheating in examination. Majority of the students at the secondary school level, however, do not have the technological skills needed for online assessment. Such lack of skills may affect achievement and attention to the examination as students may be distracted with how to operate the computer system.

The lack of technological skills is not only a problem for the students but also for the teachers who perceive the scoring of online assessment and its evaluation to be difficult. This is in line with the findings of Eyiuche and Adebowale (2020) that there was a low extent of digital disparity in ICT knowledge of secondary school teachers in Anambra state. Questions that require open-ended answers may require serious technical and computer efforts to be able to evaluate them. This is in line with the findings of Ramazan (2017) that the process of preparing and evaluating online exams and assignments requires a lot of time and effort. To do so also, the secondary schools must have a good infrastructure that can facilitate the use of online assessment, but this is lacking in most secondary schools. When it is available however, teachers may need to spend a lot of time preparing online assessment with its high cost implication. This is because, data bundles must be subscribed where the government do not provide data services. There is also, the cost of maintenance and all of these require a lot of time as perceived by secondary school teachers. Another challenge perceived by secondary school teachers is the need for orientation and training of students for online assessment. Students have to be given login identity time and shown how to submit paper, return to answered questions and how to check their internet connection.

The study also showed that secondary school teachers perceive the solutions to the challenges of online assessment to include among others: use of latest technologies that ensure good connectivity, organisation of mock assessment to familiarize students with online assessment techniques before main assessment, building feedback mechanism on any form of assessment from students. This is so because good connectivity and internet data flow facilitates the smooth administration of test and examination. And when students are familiar with the process, the teacher spends little time preparing for the assessment. Teachers also perceived that the use of online discussion and personal activity forms of online assessment, development of mal-practice check software plug-in to check access to other online platforms, use of biometric login to prevent impersonation, creation of virtual presence and professional development 
training on online assessment could mitigate the challenges of online assessment. These findings support the findings of Ramazan (2017) who reported that teachers perceived the possible solutions to online assessment to include: giving students assignments and practices that will not require memorizing but will enable them to use high-order thinking skills that will hinder them from cheating; providing students and lecturers with trainings on online assessment and evaluation practices; and increasing the encouragement and motivation of lecturers on developing online assessment and evaluation practices and using alternative evaluation techniques. Guangul, et al. (2020), also proffered preparing different questions for each student, use of online presentations, and combining various assessment methods as ways of overcoming the challenges of online assessment. In all, the test of hypotheses 1 and 2 revealed that there was no significant difference in the perceptions of secondary school teachers on the challenges and solutions to online assessment based on their digital literacy levels. Thus, at all levels of digital literacy, the same perceptions were upheld.

\section{Conclusion}

Based on the findings of the study, it was concluded that secondary school teachers' perceptions of the problems of online assessment are enough to incite unfavourable attitude towards the adoption of online assessment. However, when the teachers are given professional developmental training on how to use online assessment and other perceived solutions implemented, the use of online assessment could become an effective assessment technique for secondary school teachers.

\subsection{Recommendations}

In the light of the findings and conclusion, it is recommended that:

1) Technological installations in secondary schools should be upgraded to recent, fast and reliable computers that ensure smooth online assessment.

2) Schools should integrate the use of only WIFI internet accessible tablets for secondary school students and teachers to enhance their digital literacy level and skills.

3) School administrators should organise orientation for students and professional training for teachers on the use of online assessment.

\section{Conflict of Interest Statement}

The author declares no conflicts of interests.

\section{About the Author}

Ezeugo Nneka Chinyere was formally a Chief Lecturer in the Department of Primary Education, Nwafor Orizu College of Education, Nsugbe, where she served in various capacities like the Head, Department of Primary Education, Dean School of Early Childhood Care and Primary Education. Presently she is a Senior Lecturer in the 
Department of Educational Foundations, Nnamdi Azikiwe University Awka. She obtained a bachelors degree in Mathematics education from University of Ibadan, Masters degree in Mathematics education from the University of Nigeria Nsukka and a Doctorate degree in Measurement and Evaluation from Nnamdi Azikiwe University, Awka. Her current research interests are in the area of Measurement and Evaluation.

\section{References}

Abdulghani, A. A. (2020). E-Assessment of students' performance during the e-teaching and learning. International Journal of Advanced Science and Technology, 29(8s), 15371547.

Alruwais, N., Wills, G., \& Wald, M. (2018). Advantages and Challenges of Using eAssessment. International Journal of Information and Education Technology, 8(1), 3437. DOI: 10.18178/ijiet.2018.8.1.1008

Barbosa, H. \& Garcia-Penalvo, F. J. (2005). Importance of online assessment in the elearning process. Retrieved from https://www.researchgate.net/publication/4204731 Importance of Online Asses sment in the E-learning Process

Easy LMS B. V. (2021). What is online assessment. Retrieved from https://www.onlineassessmenttool.com/knowledge-center/assessmentknowledge-center/what-is-an-online-assessment-definition-meaning/item10639

eCom (2021). What is online assessment?
https://www.ecomscotland.com/resources/insight-what-is-online-assessment

Emmanuel, L. H. (2020). Perceptions of e-assessment by students and lecturers. International Journal of Education and Research, 8(4), 143-152.

Eyiuche, R. \& Adebowale, O. A. (2020). Appraising the extent of digital divide between music teachers and students in Anambra state secondary schools, Nigeria. International Journal of Music Studies, 2(1), 26-43.

Fedelis, R. \& Harwati, H. (2021). Primary school teachers' usage and perception of online formative assessment tools in language assessment. International Journal of Academic Research in Progressive Education \& Development, 10(1), 291-303. DOI:10.6007/IJARPED/v10-i1/8846

Gomathy, C. K. (2018). A study on the effect of digital literacy and information management. Journal of Scientific Research and Review, 7(3), 51-57.

Guangul, F. M., Suhail, A. H., Khalit, M. I. Khidhir, B. A. (2020). Challenges of remote assessment in higher education in the context of COVID-19: a case study of Middle East College. Educ Asse Eval Acc 32, 519-535. https://doi.org/10.1007/s11092-020$\underline{09340-\mathrm{w}}$

Kearns, L. R. (2012). Student assessment in online learning: Challenges and effective practices. MERLOT Journal of Online Learning and Teaching 8(3) https://jolt.merlot.org/vol8no3/kearns 0912.pdf 
Mariam, Y. M. A. (2021). Full-time online assessment during covid-19 lockdown: EFL teachers' perceptions. Asian EFL Journal Research Articles, 28(1), 1-22.

Masters, G., Thomson, S. \& Schleicher, A. (2017). Assessment online: informing teaching and learning. https://www.teachermagazine.com/au en/

Mayotte, S. (2012). Online assessment. https://www.igi-global.com/chapter/onlineassessment $/ 64775$

Mirza, H. S. (2021). University teachers' perception of online assessment during the Covid-19 pandemic in Lebanon. American Academic $\mathcal{E}$ Scholarly Research Journal. 13(1)

Noradila, I., Nishantini, G. \& Nur, S. A. M. (2021). Students' perception towards the usage of online assessment in university Putra Malaysia amidst COVID-19 pandemic. Journal of Research in Humanities and Social Science, 9(2), 09-16.

Nworgu, B. G. (2015). Educational research: Basic issues and methodology. Ibadan: wisdom Publisher Limited.

Ramazan, Y. (2017). Problems experienced in evaluation success and performance in distance education: A case study. Turkish Online Journal of Distance EducationTOJDE, 18(1), 39-51.

Strunc, A. (2020). Editorial: Are They Listening? Policymakers and Their Role in Public Education. Research in Educational Policy and Management, 2(1), i-iii. https://doi.org/10.46303/repam.02.01.ed

The World Bank (2020). How countries are using EdTech (including online learning, radio, television, texting) to support access to remote learning during the COVID-19 pandemic. Retrieved from https://www.worldbank.org/en/topic/edutech/brief/howcountries-are-using-edtech-to-support-remote-learning-during-the-covid-19pandemic

Vlachopoulos, D. (2020). COVID-19: Threat or opportunity for online education? Higher Learning Research Communications, 10(1). https://doi.org/10.18870/hlrc.v10i1.1

Western Sydney University (2020). What it Digital literacy? https://www.westernsydney.edu.au/studysmart/home/study skills guides/digit al literacy/what is digital literacy. 

will be applied to their work. Under the terms of this license, no permission is required from the author(s) or publisher for members of the community to copy, distribute, transmit or adapt the article content, providing a proper, prominent and unambiguous attribution to the authors in a manner that makes clear that the materials are being reused under permission of a Creative Commons License. Views, opinions and conclusions expressed in this research article are views, opinions and conclusions of the author(s). Open Access Publishing Group and European Journal of Education Studies shall not be responsible or answerable for any loss, damage or liability caused in relation to/arising out of conflicts of interest, copyright violations and inappropriate or inaccurate use of any kind content related or integrated into the research work. All the published works are meeting the Open Access Publishing requirements and can be freely accessed, shared, modified, distributed and used in educational, commercial and non-commercial purposes under a Creative Commons Attribution 4.0 International License (CC BY 4.0). 